\author{
Eukasz Godlewski (D)
}

Uniwersytet w Białymstoku

\title{
SPÓR O POWOŁANIE KOŚCIOŁA NARODOWEGO W KORONIE W OKRESIE SOBORU TRYDENCKIEGO (1545-1563)
}

\author{
ABSTRACT \\ Debate on the Creating of the Polish National Church \\ in the Times of the Council of Trent (1545-1563)
}

In the time of the Council of Trent, the Polish nobility often and loudly demanded the forming of the Polish National Church, which would enable them to execute state control over the clergy, its activity, and church property. Popular Protestant ideas coherent with such an idea fulfilled the role of useful weapon in their struggle against the clergy. Even though the idea of the church reform converged with many changes postulated by the contemporary noble reform movement, the state finances, homogeneity of Crown lands and the Polish-Lithuanian union took predominance over church matters. Appropriate conduct of debate, disabling discussion about a reform, was promoted by the clergy itself, which was not interested in loosening their dominant position in the society and becoming subject to civic laws. Protestant deputies to the parliament, who constituted the majority in the lower chamber, could have acquired more benefits, were it not for their reluctance to impose certain solutions on the Catholics, who still dominated in the society. The clergy, in particular bishops, sought some compromise with Protestants, until the Catholic Church itself undertook mild reforms in the third phase of the Council of Trent. The stand of the Polish monarch, Sigismundus Augustus, who - having been raised as a Catholic - opposed the forming of new church and his attitude was also important.

Keywords: national church, national religious council, struggle over the form of the Church in the Polish Crown

Słowa kluczowe: Kościół narodowy, sobór narodowy, walka o kształt Kościoła w Koronie 
Kwestią powstania Kościoła narodowego w Koronie w XVI w. szeroko omówił Edward Bałakier ${ }^{1}$. Problemem tym zajmowali się również m.in.: Bronisław Dembiński, Czesław Frankiewicz, Feliks Flaczyński i Stanisław Litak². Brak syntetycznego spojrzenia na związek przyczynowo-skutkowy postulatów szlacheckich i instytucji monarszej na sejmach koronnych, nieuwzględnienie oddziaływania reform soboru trydenckiego, nowe metody badawcze oraz nieprecyzyjne wnioski wymienionych badaczy obligują historyków do ponownego przeanalizowania tego problemu.

Prekursorem myśli o Kościele narodowym był w XV w. Jan Ostroróg, który w dziele Monumentum pro Reipublicae Ordinatione z 1477 r. piętnował zależność Polski od papiestwa, krytykował chciwość i symonię duchownych, zbyt poważny udział Niemców w życiu kościelnym i głoszenie kazań w języku niemieckim. Postulował jednocześnie podporządkowanie Kościoła i duchowieństwa państwu33. Idee XVI-wiecznych reformatorów dotarły natomiast do Korony na początku lat dwudziestych XVI w. Przyczyn postulowania powołania niezależnego od Rzymu Kościoła w Polsce należy doszukiwać się w podłożu politycznym i gospodarczym, a nie wyznaniowym. Zarzuty wobec nadmiernej pazerności dostojników kościelnych stawiane były praktycznie przez cały okres panowania króla Zygmunta Augusta. Szlachta chętnie sięgała do argumentów wskazujących na negatywne skutki zależności od Rzymu czy bogacenie się duchowieństwa kosztem stanu szlacheckiego. Reformacja w Koronie była dla szlachty narzędziem walki z duchowieństwem, a nie przyczyną ich wzajemnego konfliktu. Celem szlachty było osiągnięcie przewagi w państwie nad duchowieństwem i rozciągnięcie kontroli państwowej nad sprawami i dobrami kościelnymi. Drogę do realizacji tych zamiarów widziano w zorganizowaniu Kościoła narodowego, który przy zachowaniu dotychczasowej organizacji uniezależniłby się od Rzymu. Do utworzenia takiego Kościoła niezbędna była zgoda trzech stanów sejmujących, a zwłaszcza instytucji monarszej, która stanęłaby na czele takiego Kościoła i roztoczyłaby nad nim swoją kontrolę.

W tym samym czasie, gdy papież Paweł III przygotowywał sobór powszechny do Trydentu, szlachta koronna na sejmikach postulowała utworzenie polskiego Kościoła narodowego. Andrzej Frycz Modrzewski w 1543 r. w swoim powstałym w Krakowie dziele Oratio de legatis ad concilium christianum mittendis sugerował monarsze, aby ten przed soborem powszechnym zwołał w Polsce synody diecezjalne i prowincjonalne, na które wstęp mieliby

E. B a ła ki er, Sprawa kościota narodowego w Polsce XVI wieku, Warszawa 1962.

2 B. Dembiński, Kwestia soboru narodowego w Polsce, [w:] Pamiętniki Drugiego Zjazdu Historyków Polskich we Lwowie, t. 1, Lwów 1890; C. Frankiewicz, Ze studiów nad soborem narodowym w Polsce, Rzeszów 1914; F. Flaczyński, Idea Kościota narodowego w Polsce w XVI w., „Ateneum Kapłańskie” 1911, t. 5; S. Litak, Kościót w Polsce w okresie reformacji i odnowy potrydenckiej, [w:] Historia Kościota, t. III: 1500-1715, red. L.J. Rogier, R. Aubert, M.D. Knowles, tłum. J. Piesiewicz, Warszawa 1986.

3 A. Pawiński, Jana Ostroroga żywot i pismo O Naprawie Rzeczypospolitej, Warszawa 1884, s. 123-181. 
również innowiercy ${ }^{4}$. Apel Modrzewskiego nie skłonił króla do włączenia się w te plany. Zygmunt I wychowany w wierze katolickiej i opierający się w swych rządach na możnych, w tym senatorach duchownych, konsekwentnie stał po stronie Kościoła katolickiego i nie dopuszczał do znacznego wzmocnienia nurtów protestanckich w Koronie. Król prowadził politykę balansowania między szlachtą a Kościołem. Z jednej strony przyznawał miastom pruskim prawo do wolności wyznania, a z drugiej popierał Stolicę Apostolską i nie godził się na zwołanie synodu krajowego. Śmierć króla i przejęcie pełni władzy przez Zygmunta Augusta otwierało w mniemaniu szlachty nowe możliwości w walce z Kościołem i możnowładztwem. W nowym królu szlachta upatrywała sojusznika, który wspólnie z nią przeprowadzi reformę państwa.

Już na pierwszym sejmie podczas samodzielnych rządów Zygmunta Augusta (piotrkowski 1548 r.) szlachta podniosła kwestię zwołania soboru narodowego. Próba unieważnienia królewskiego ślubu z Barbarą Radziwiłłówną tak bardzo jednak zdominowała obrady sejmowe, że nie podjęto żadnych rozmów w tej sprawie. Posłowie i senatorowie, w tym również duchowni, przybyli na sejm w atmosferze ogólnego poirytowania poczynaniami Zygmunta Augusta, gdyż związek ten uznali za mezalians godzący w powagę dynastii i państwa ${ }^{5}$. Prawdziwym powodem wzburzenia była jednak obawa rycerstwa, że przyszłe potomstwo Zygmunta Augusta z Barbary Radziwiłłówny (przedstawicielki najsilniejszego litewskiego rodu) umocni dziedziczność stolca hospodarskiego, a to zagrozi w przyszłości wolnej elekcji w Koronie. Na sejmie 1548 r. Zygmuntowi Augustowi nie udało się pozyskać dla swojej sprawy wsparcia duchowieństwa. Spór króla z przedstawicielami Kościoła spowodował, że monarcha nie przeszkodził zwolennikom nauki Jana Kalwina w zwołaniu przez nich w 1550 r. do Pińczowa synodu, na którym wybrali na superintendenta Małopolski Feliksa Krzyżaka ze Szczebrzeszyna ${ }^{6}$. Protestanci tym samym ukazali nie tylko swoją polityczną siłę, ale również cel, jakim było utworzenie własnego Kościoła. Powstanie pierwszej superintendentury zaniepokoiło duchowieństwo, które podjęło działania zmierzające do osłabienia pozycji innowierców. Prymas Mikołaj Dzierzgowski, gorący przeciwnik małżeństwa królewskiego, 7 grudnia 1550 r. ukoronował Barbarę Radziwiłłównę na królową Polski. W zamian uzyskał obietnicę Zygmunta Augusta, że odstępcy od Kościoła katolickiego będą uznawani za heretyków i pozbawiani czci oraz majątku ${ }^{7}$ Monarcha już 12 grudnia 1550 r. wydał dekret, w którym zobowiązał się nie przyjmować heretyków do

4 A.F. Modrzewski, Ad Regem Pontifices, Presbyteros, et Populos Poloniae ac reliquae Sarmatiae, Oratio Andreae Fricii Modrevii de Legatis ad Concilium Christianum mittendis, Kraków 1546.

5 I. Kaniewska, Matopolska reprezentacja sejmowa za czasów Zygmunta Augusta 1548-1572, „Zeszyty Naukowe Uniwersytetu Jagiellońskiego" 1988, z. 48, s. 94.

6 S. Gołębiowski, Czasy Zygmunta Augusta, Wilno 1851, s. 29.

7 W. Pociecha, Arcybiskup gnieźnieński Mikotaj Dzierzgowski prymas Polski, „Nasza Przeszłość: studia z dziejów Kościoła i kultury katolickiej w Polsce" 1947, t. 2, s. 37-102; A. Sokołow ski, Dzieje Polski ilustrowane, t. III: Epoka Jagiellońska, Warszawa 1900, s. 303-304. 
senatu i nie powierzać im urzędów oraz godności. Zygmunt August obiecał także wygonić z kraju tych, którzy nie powrócą na łono Kościoła katolickiego ${ }^{8}$. Działania króla były jednak bezprawne, wymagały bowiem zatwierdzenia przez sejm. Monarszy dekret naruszał prawa i swobody szlacheckie zawarte w konstytucji nibil novi. Łamanie postanowień konstytucji piotrkowskiej z 1505 r. mogło ściągnać wobec tego gniew całej szlachty, protestanckiej i katolickiej, na biskupów i króla. Szlachta mogła odebrać to bowiem jako zamach na swoją wolność osobistą. Należało uchwalić konstytucję sejmową, której postanowienia przychylałyby się do stanowiska monarchy.

Wydarzenia z końca 1550 r. doprowadziły wśród protestantów do obaw o represje ze strony biskupów. Nastąpiła szeroka i szybka mobilizacja szlachty innowierczej i to do tego stopnia, że na kolejnym sejmie piotrkowskim tego samego roku po raz pierwszy izbę poselską w większości stanowili innowiercy ${ }^{9}$. Podczas sejmu szlachta wystąpiła do króla z postulatem synodu walnego w Koronie, „aby król J. M. różnice między duchownymi a świeckimi znieść raczył, aby stan duchowny nie pociągał ludzi szlacheckich jako heretyków do więzienia, nie pozywał do sądu [...], jedno na walny sejm wedle statutu Casimiri Magni [...], aby pod władzą jednego króla nie żył naród jak potwór posiadający odrębne prawa"10. Należy zaznaczyć, że również znaczna część katolickiej szlachty pokładała w takim soborze liczne nadzieje. W ich mniemaniu miał on załagodzić spory między stanem duchownym i świeckim. Co ważniejsze, naród polityczny zapowiadał, że jeżeli dojdzie do koncylium, to zostaną na nim uchwalone reformy kościelne: komunia pod dwiema postaciami, liturgia w języku narodowym oraz zniesienie celibatu księży. Podkreślam jednak, że szlachta katolicka mówiła o reformie Kościoła, a nie zmianie wyznania i zerwaniu z Rzymem, choć zapewne znaczna część protestantów w zwołaniu soboru widziała jeden z głównych celów. Koncepcję reformy zaczął popierać sam Zygmunt August. Monarcha wyraził bowiem chęć zwołania soboru narodowego, który doprowadziłby do pojednania z protestantami, ale za zgodą papieża. Co ciekawe, alternatywę taką popierała spora część biskupów. Analogicznie jak dla monarchy, tak również dla wyższych duchownych przy zwołaniu koncylium nie mogło być żadnej mowy o zerwaniu ze Stolicą Apostolską, co najwyżej o poszerzeniu autonomii Kościoła w Koronie ${ }^{11}$.

Prymas Dzierzgowski nie poparł jednak rokowań z protestantami. Ośmielony wydanym dekretem przeciw heretykom i otrzymaną łaską monarszą za koronowanie Barbary Radziwiłłówny zmobilizował biskupów do działania. Zwołał kolejny synod do Piotrkowa (1551 r.), na którym uchwalono szereg przepisów wymierzonych przeciwko protestantom.

8 W.Zakrzewski, Powstanie i wzrost reformacji w Polsce 1520-1572, Lipsk 1870, s. 61-62.

9 A. Suchen i-G rabowska, Spory królów ze szlachtą z ztotym wieku. Wokót egzekucji praw, Kraków 1988, s. 46-48.

10 Articuli in Conventu Piotrcoviensi Anno 1550, [w:] Scriptores Rerum Polonicarum, t. I: Dyaryusze sejmów koronnych 1548, 1553, 1570, wyd. J. Szu j ski, Kraków 1872, s. 41.

11 E. Bałakier, op. cit., s. 267-269. 
Najważniejszym był jednak zakaz oddawania dóbr kościelnych w ręce osób podejrzanych o herezje. Potwierdzono również postanowienia z 1527 r. odnośnie do inkwizytorów, precyzując przy tym ich opatrzenia za wykonywaną pracę. Ponadto, jak czytamy w uchwałach synodu:

W celu usunięcia herezji luterskiej, która w prowincji gnieźnieńskiej silnie wzrosła i zapuściła korzenie i wiele osób stany duchownego porwała i zaraziła, według postanowienia tegoż św. Synodu zebrani w Panu Najprzewielebniejsi arcybiskup i biskupi obecni, a za nieobecnych posłowie, uczynili wyznanie wiary katolickiej, którą św. Kościół rzymski wyznaje, a które zobowiązani są uczynić także poszczególni biskupi nieobecni, dalej prałaci i kanonicy kościołów katedralnych i kollegiatur w swych kapitułach, oraz wszyscy z osobna opaci ze swymi klasztorami, a także plebani i reszta kapłanów i kleryków wobec archidiakona w czasie wizytacji kościołów parafialnych ${ }^{12}$.

Duchowni bardzo szybko rozpoczęli wprowadzać w życie uchwały ostatniego synodu, a ich sądy zaczęły orzekać konfiskatę dóbr i banicje wobec „heretyków”. Prymas jedynie pozornie mógł sobie jednak pozwolić na dość dużą swobodę w walce z protestantami. Dekret z 12 grudnia 1550 r. nie uzyskał aprobaty całego gremium prawodawczego - sejmu. W konsekwencji tego starostowie ani myśleli egzekwować wyroki sądów kościelnych w sprawie herezji szlachciców. Takie postępowanie duchownych wprowadziło mimo wszystko niepokój i to nie tylko w szeregach innowierców, ale również katolickiej szlachty, zwłaszcza tej, która widziała Kościół katolicki jako oponenta politycznego i domaga się jego reformy oraz ograniczenia wpływu duchownych w państwie. Obawy szlachty spotęgował fakt, że Zygmunt August potwierdził i nakazał wykonać wyrok w sprawie o herezję i utratę wszelkiego mienia ruchomego i nieruchomego na księżach Stanisławie Orzechowskim i Marcinie Krowickim za pojęcie żon. Zwalczanie przez prymasa dysydentów uniemożliwiło porozumienie się protestantów z hierarchią kościelną. W wyniku tego we wszystkich zachowanych instrukcjach sejmików przedsejmowych sejmu piotrkowskiego $1552 \mathrm{r}$. szlachta, zamiast postulować koncepcję zwołania soboru narodowego i egzekucji dóbr, domagała się zniesienia jurysdykcji wyroków duchownych ${ }^{13}$. Działanie kleru wymierzone bezpośrednio w protestancką szlachtę doprowadziło do przewartościowania postulatów szlachty. Naród polityczny obawiał się, że duchowni będą w stanie egzekwować na nich

12 Constitutiones Synodi Piotrcoviensis 1551, [w:] W. Wisłocki, Andrzeja na Więcborku Zebrzydowskiego, biskupa wtoctawskiego i krakowskiego korespondencyja z lat 1546-1553: z przydaniem Synodów z r. 1547 i 1551, jako też innych dokumentów wspótczesnych, Kraków 1878, s. 513-525; P.W. Fa bisz, Wiadomość o synodach prowincjonalnych i diecezjalnych gnieźnieńskich i o prawach Kościota Polskiego, Kępno 1861, s. $165-166$.

13 W. Kriegseisen, Stosunki wyznaniowe w relacjach państwo-kościót między reformacją a oświeceniem, Warszawa 2010, s. 645-653; W. Z a kr z e w sk i, op. cit., s. 64-66. 
wyroki swoich sądów. Kościół był coraz śmielszy w swoich działaniach wobec innowierców i przy ówczesnym poparciu Zygmunta Augusta istniało dość duże prawdopodobieństwo, że kler uzyska narzędzia do egzekwowania swoich wyroków o infamię na „heretykach”. Szlachta działała zatem przemyślanie i w zależności od sytuacji wewnętrznej przewartościowywała swoje postulaty.

Na marszałka sejmu piotrkowskiego 1552 r. rycerstwo wybrało Rafała Leszczyńskiego, jednego z przywódców ruchu egzekucyjnego i reformacji w Polsce ${ }^{14}$. Leszczyński domagał się wraz z grupą szlachty cofnięcia wydanych przez króla dekretów, które godziły w prawa innowierców, a jednocześnie całej szlachty. Zagrożono, że w przeciwnym razie izba poselska nie będzie stanowić nowych praw. Izbę poselską poparli świeccy członkowie senatu, tak iż duchowni zostali osamotnieni. Niewątpliwie zatem przytoczone dekrety monarsze zostały uznane za pogwałcenie wolności osobistej szlachty. Zygmunt August opowiedział się jednak po stronie duchownych. Jak czytamy w diariuszu sejmu: „JKM nie chce się w to wdawać, aby któremu stanowi praw ubliżyć miał, jak wam rycerstwu swemu lub też i księży. Iż księża powiadają iż to ich jurysdykcji należy [wyłączność sądzenia w kwestiach wiary], tedy się mu nie godzi w to wdawać, aby my ich wolności mieli kadzić" ${ }^{15}$. Członkowie izby poselskiej nie zgodzili się jednak z monarszą argumentacją, a marszałek ostro zaatakował duchownych członków senatu: „Oto są nauczyciele nasi, królu, którzy nas niewinni czci i życia chcą pozbawić, niepomni owych słów: hipokryto! Wyjmij wprzód tram z własnego oka. O to są siedzą w owczej skórze, ukrywając wewnątrz drapieżnego wilka"16. Wojewoda krakowski Jan Tarnowski próbował pogodzić posłów z duchownymi, proponując kompromisowe rozwiązanie: „Jeżeli kto heretyk, niech podlegnie karze [...] ale niech sądzi król z senatem, duchowni do senatu należą a więc i do sądu"17. Sytuacja zaczęła wymykać się Zygmuntowi Augustowi spod kontroli, istniała realna groźba zerwania sejmu, dlatego też król postanowił zmienić swoje stanowisko. Oznajmił, że sądy w sprawach o herezję podług praw dawnych i dawnej pobożności należą do biskupów, ale żeby odnaleźć sposób pogodzenia praw rycerstwa z prawem duchowieństwa, na okres jednego roku zawiesza jurysdykcję ich sądów nad szlachtą. Obiecał również zwołanie w Koronie soboru narodowego „concilium nationale”, na którym zostaną uzgodnione prawa polskie i prawa biskupów ${ }^{18}$. Wydaje się, że próbowano powrócić do koncepcji Kościoła narodowego przedstawionej na sejmie w 1550 r.

14 M. Sipayłło, Leszczyński Rafat ok. 1526-1592, [w]: Polski stownik biograficzny, t. 17, Warszawa 1972, s. 133-135.

15 Akta sejmu piotrkowskiego roku 1552, [w]: Dyaryusze sejmów koronnych..., s. 49.

16 Ibidem, s. 50.

17 Ibidem, s. 269.

18 Ibidem, s. 49-50; Archiwum Główne Akt Dawnych [dalej: AGAD], Metryka koronna [dalej: MK], t. 82, k. 150: Sigismundus Augustus polish rex suspenditur; B. Ku m o r, Historia Kościota, t. V: Czasy nowożytne roztam w chrześcijaństwie zachodnim, Lublin 2002, s. 142; J. Moraczewski, Dzieje Rzeczypospolitej Polskiej z pierwszej potowy szesnastego wieku, Poznań 1849, s. 200-203. 
Walka między izbą poselską a duchownymi członkami senatu na kolejnym sejmie (krakowskim, 1553 r.) była bardzo stonowana. Rycerstwo, oddaliwszy od siebie niebezpieczeństwo sądów duchownych, postanowiło skupić swoją uwagę na kwestii egzekucji dóbr, podatków oraz limitacji sądów monarszych ${ }^{19}$. Mimo uspokojenia sytuacji w państwie szlachta kolejny raz nie podnosiła na forum sejmowym kwestii powołania Kościoła narodowego. Priorytetem szlachty była egzekucja praw, egzekucja dóbr, reforma sądownictwa oraz ujednolicenie Korony. Nie należy tym samym zgodzić się z Bałakierem, jakoby szlachta nieustanie i wytrwale walczyła o powstanie Kościoła narodowego w Polsce ${ }^{20}$. Następny rok również nie przyniósł zmian prawnych w materii Kościoła narodowego, gdyż sejm lubelski 1554 r. „rozsypał się” i nie obrano prawdopodobnie nawet marszałka ${ }^{21}$.

Zygmunt August ze złożonej szlachcie obietnicy zwołania soboru narodowego pragnął wybrnąć obronną ręką. W listopadzie 1554 r. listownie zawiadomił papieża Juliusza III o wzmocnieniu tendencji protestanckich w Koronie i konieczności szybkiego działania, żeby uniknąć sytuacji, jaka panowała na terenie cesarstwa. Monarcha stanowczo opowiedział się po stronie Kościoła katolickiego i prosił, aby takiemu synodowi przewodniczył legat papieski, który doprowadzi do pojednania chrześcijan w Polsce i powrotu wszystkich na łono Kościoła powszechnego ${ }^{22}$. Zygmunt August tym samym odrzucał możliwość powołania Kościoła narodowego.

Porażka przedstawicieli stanu duchownego w starciu z izbą poselską na sejmie $1552 \mathrm{r}$. wzmocniła protestantów w Koronie i de facto doprowadziła do przyśpieszenia wzrostu liczebności członków wyznań reformowanych. Do konwersji skłaniało także przechodzenie wybitnych jednostek na wyznania reformowane, jak np. Jana Łaskiego, Mikołaja Reja czy Jakuba Przyłuskiego. Jeszcze większe znaczenie na wzrost konwersji miał fakt, że czołowi przedstawiciele rodzin możnowładczych skłaniali się do nowych reformowanych wyznań. Zjawisko te szczególnie dotyczyło: Zborowskich, Ostrorogów, Oleśnickich, Firlejów, Bonerów, Tomickich, Stadnickich, Szafrańców, Myszkowskich, Górków. Reformacja w Koronie jeszcze bardziej zaczęła przybierać na sile, gdy na jej terenach pojawili się członkowie Kościoła ewangelicko-reformowanego ${ }^{23}$. O ile wcześniej istniał dość duży opór wśród ludności do konwersji na „luteranizm”, w związku z tym, iż w Polsce stroniono od tego, co

19 Dyaryusz sejmu krakowskiego 1553, [w:] Dyaryusze sejmów koronnych..., s. 1-16; AGAD, MK, t. 83, k. 197203; Sejm Walny Krakowski 1553 r., [w:] Volumina Constitutionum [dalej: VC], t. I: 1493-1549, cz. 2, oprac. I. Dwornicka, S. Grodziski, W. Uruszczak, Warszawa 2000, s. 47-60.

20 E. Bałakier, op. cit., s. 165-166.

21 AGAD, MK, t. 85, k. 73-84: „Post paucos dies nobilitas volutatur...”; I. Kani e w ska, op. cit., s. 103; Wstęp, [do:] Sejm Walny Lubelski 1554 r., [w:] VC, t. I, cz. 2, s. 62.

22 Zygmunt August do Juliusza III, prosi o przestanie legata na synod narodowy, listopad 1554 r., [w:] Uchańsciana, czyli zbiór dokumentów wyjaśniających życie i dziatalnoś́ Jakóba Uchańskiego, t. IV, Warszawa 1892, s. 179-181.

23 E. Go dlew ski, Szlachta a duchowieństwo na sejmach w latach czterdziestych ipięídziesiątych w XVI wieku, „Saeculum Christianum” 2016, t. 23, s. 155. 
niemieckie, o tyle tego dylematu nie było w przypadku zwolenników nauki Jana Kalwina, wywodzącego się z reformacji szwajcarskiej² ${ }^{24}$ Wnikliwszych badań wymaga kwestia czynników wpływających na rozwój wyznań reformowanych w Koronie ze strony „luterańskich” Prus Książęcych.

Bezsilność kleru w walce ze szlachtą skłaniała przedstawicieli ruchu egzekucyjnego do coraz śmielszych żądań i ograniczenia wpływów Kościoła katolickiego. Jednak wraz z upływem terminu zawieszenia jurysdykcji duchownych nad szlachtą księża ponownie zaczęli występować z licznymi pozwami o herezję. Zagadnienia reformacyjne i związana z nimi kwestia wiary i Kościoła ponownie stawały się priorytetami w postulatach szlachty. Również Zygmunt August dostrzegał, że należy uporządkować relacje między Kościołem a szlachtą. W legacjach wysyłanych na sejmiki wyraźnie podkreślił, że kolejny sejm (piotrkowski 1555 r.) ma się zająć kwestiami wyznaniowymi, w tym jurysdykcją duchownych. O powadze tematyki sejmu świadczy fakt, że obie strony konfliktu dokonały mobilizacji swoich sił. Na sejm przybył komplet biskupów polskich, za wyjątkiem chorego biskupa kamienieckiego Leonarda Słończewskiego, a izba poselska została zdominowana prawie całkowicie przez protestantów - 113 na 115 posłów było innowiercami. Ponadto w ławach sejmowych zasiedli najznakomitsi oratorzy i znawcy prawa: Rafał Leszczyński, Jakub Ostroróg i Mikołaj Sienicki. Przedstawiciele Kościoła katolickiego nie chcieli jednak układać się z protestantami i już w pierwszych dniach sejmu zaprzepaszczono możliwość osiągnięcia kompromisu, a co za tym idzie powstania Kościoła narodowego ${ }^{25}$. Układ sił w sejmie musiał doprowadzić do sukcesu zwolenników wyznań reformowanych, gdyż de facto zdanie izby poselskiej było kluczowe w formułowaniu konstytucji sejmowych. Zgodnie z treścią konstytucji tegoż sejmu każdy w kwestii wiary mógł sam stanowić w swoich dobrach, zawieszono sądy duchowne do odwołania i anulowano dotychczasowo wydane wyroki w sprawach o herezję ${ }^{26}$. Tym samym zaaprobowano działania szlachty innowierczej, która rugowała księży katolickich, a w ich miejsce obsadzała protestanckich duchownych. Członkowie izby poselskiej przedłożyli również królowi i senatowi konfesję augsburską w skróconej wersji. Monarcha ponownie zobowiązał się do zwołania soboru narodowego i zgodził się w tej sprawie wysłać posła do Rzymu. Należy zwrócić uwagę, że spór o jurysdykcję sądów duchownych nad szlachtą uniemożliwiał porozumienie się w kwestii powołania Kościoła narodowego. Ilekroć szlachta próbowała pozbawić stan duchowny tego przywileju, obrady przeistaczały się w zażartą walkę, która prowadziła do nieustępliwości każdej ze stron.

${ }_{24}$ J. Wijaczka, Luteranie w Koronie od 1517 do 1795 r., [w:] Kościoty luterańskie na ziemiach polskich (XVI-XX w.), t. I: W czasach Rzeczpospolitej Obojga Narodów, red. J. Kłaczkow, Toruń 2012, s. 13-32; W. Zakrzewski, op. cit., s. 41.

25 Dzienniki sejmów walnych koronnych za panowania Zygmunta Augusta Króla polskiego i W. X. Litewskiego 1555 i 1558 r. w Piotrkowie ztożonych, wyd. J.T. Lu bo m i r ski, Kraków 1869, s. 6-43.

26 E. Godlewski, op. cit., s. 156-158. 
Zygmunt August do nowo wybranego papieża Pawła IV w grudniu 1555 r. wysłał Stanisława Maciejowskiego. Giovanni Pietro Carafa w przeciwieństwie do swojego poprzednika Giovanniego Marii Ciocchi del Monte (Juliusza III) był przeciwny kontynuowaniu obrad soboru trydenckiego. Paweł IV reformy chciał wprowadzać samodzielnie, opierając się głównie na odnowionej inkwizycji. Był przeciwny jakimkolwiek negocjacjom z protestantami, uważając ich za heretyków, których należy spalić na stosie. Wrogość nowego papieża do protestantów najprawdopodobniej była już na początku jego pontyfikatu dobrze znana Zygmuntowi Augustowi z racji wcześniejszej działalności duchownego (od 1542 r.) w trybunale Kongregacji Świętego Oficjum ${ }^{27}$. Monarcha mimo to, zamiast prosić o zgodę na sobór powszechny w Koronie, postulował narodowy, na którym pragnął udzielić zgody na: odprawianie mszy w języku polskim, udzielanie komunii pod dwiema postaciami oraz zniesienie celibatu księży. Ustępstwa dla dysydentów miały zapobiec, w mniemaniu króla, wojnie domowej. Mimo iż od narodzin reformacji podobne postulaty padały w całej Europie, zostały one odrzucone. Papież wyraził wręcz swoją daleko idącą dezaprobatę dla króla polskiego, że mógł w ogóle prosić następcę Świętego Piotra o zaakceptowanie takich koncesji. Ze względu jednak na Polskę zobowiązał się przyspieszyć zwołanie kolejnego etapu soboru trydenckiego ${ }^{28}$. Zygmunt August zapewne spodziewał się odmowy ze strony papieża, ale działając pragmatycznie, spełnił postulat izby poselskiej i zyskał dodatkowy czas na stonowanie nastrojów religijnych w Koronie.

Powszechna świadomość wśród rycerstwa, że monarcha nie zwoła soboru narodowego bez zgody Stolicy Apostolskiej, dodatkowo wyhamowała na kolejnych sejmach jego żądania w tej kwestii. Szlachta zapewne zdawała sobie sprawę, że dopóki na Stolicy Piotrowej zasiada Paweł IV, Zygmunt August nie otrzyma zgody, a więc projekt ich w tym momencie nie ma szans realizacji i to nie z winy króla, ale papieża. Biskupa rzymskiego w jego polityce religijnej na terytorium Korony wspierał od października 1555 r. legat Luigi Lippomano ${ }^{29}$. Nuncjusz nie otrzymał jednak wystarczającego wsparcia ze strony biskupów, a nawet wręcz przeciwnie sporej jej części się naraził. Wysłannik papieski poszukał wobec tego zaplecza wśród kleru niższego szczebla i rozpoczął prace nad rozwojem szkół, podnoszeniem wykształcenia duchownych oraz ukróceniem występków kleryków ${ }^{30}$. Można powiedzieć, że kroki te były próbą reformy Kościoła w Polsce, ale trudno mówić o bezpośrednim działaniu kontrreformacyjnym.

Nuncjusz z upływem czasu stawał się jednak coraz bardziej śmiały w swoich poczynaniach. 6 września 1556 r. doprowadził nawet do zwołania synodu prowincjonalnego

27 R. Fischer-Wollpert, Leksykon papieży, tłum. B. Białe cki, Kraków 1996, s. 134-135.

28 List księcia di Palliano do nuncjusza Lipomana, [w:] Relacye nuncyuszów apostolskich i innych osób o Polsce od roku 1548 do 1690, t. 1, wyd. E. Rykacz zewsk i, Poznań 1864, s. 29-31; Biblioteka Kórnicka Polskiej Akademii Nauk, 22885-1: Relacye nuncyuszów apostolskich i innych osób o Polsce od roku 1548 do 1690.

29 P.W. Fabisz, Wiadomość o legatach i nuncjuszach apostolskich w dawnej Polsce (1075-1863), Ostrów 1864, s. $129-134$.

30 W.Zakrzewski, op.cit., s. 101-103. 
w Łowiczu, na którym wskazał w credo różnice między protestantami a katolikami oraz domagał się u monarchy zamknięcia szkół wyznań reformowanych. Uchwałą synodu odmówiono ponadto świeckim komunii pod obiema postaciami ${ }^{31}$. Wszystkie te działania utrudniały porozumienie się katolików z protestantami, a więc również powstanie Kościoła narodowego.

Zrealizowaniu koncepcji Kościoła narodowego nie pomagała zwłaszcza postawa Zygmunta Augusta. Król, zaabsorbowany zagrożeniem dla Inflant i przygotowaniami do wojny, kwestie religijne odsuwał na dalszy plan. W celu jednak uspokojenia sytuacji w kraju pod swoją przyszłą nieobecność wydał dwa dekrety, które miały chwilowo zaspokoić oczekiwania dwóch stron konfliktu. Pierwszy zakazywał usuwania katolickich księży z kościołów i obsadzania duchownych w parafiach bez zgody biskupów. W drugim dekrecie potwierdził wolność wyznaniową szlachty i zawiesił jurysdykcję duchownych w sprawach o herezję $e^{32}$.

Na kolejnym sejmie (Warszawa, 1556/1557 r.) kwestia powstania Kościoła narodowego nie została uwzględniona w postulatach szlachty. Obrady zdominowała jurysdykcja sądów duchownych. Zygmunt August, widząc brak możliwości osiągnięcia konsensusu, dążył do konkluzji i uchwalania podatków ${ }^{33}$. W styczniu 1557 r. wydał konstytucję, w myśl której ustanowił kolejne interim, czyli utrzymał w mocy prawo zawieszenia jurysdykcji duchownych uchwalone w $1552 \mathrm{r}^{34}$

Przełom w powstaniu Kościoła narodowego mógł nastąpić na kolejnym sejmie, piotrkowskim 1558/1559 r. Głównym tematem obrad sejmu miała być kwestia egzekucji dóbr i wyboru przyszłego monarchy w obliczu nieposiadania potomka przez Zygmunta Augusta. Pośrednio szlachta wybierała się jednak na ten sejm również z zamiarem dyskusji na temat kształtu Kościoła w Koronie i uregulowania ostatecznie kwestii prawnych pomiędzy nią a duchownymi ${ }^{35}$. Sejm ten w mniemaniu szlachty miał ostatecznie doprowadzić do wdrożenia w życie większości postulatów ruchu egzekucyjnego. W toku obrad zwołania soboru narodowego domagali się już nie tylko zwolennicy kompromisu z protestantami, na których czele stanął biskup włocławski Jakub Uchański, ale również zagorzali katolicy, jak np. wojewoda sieradzki Janusz Kościelecki czy kanclerz koronny Jan Ocieski ${ }^{36}$. Odraczanie przez papieża Pawła IV zwołania soboru powszechnego i brak gruntownych reform w Kościele przysparzały zwolennikom soboru narodowego nowych stronników. Namowy

31 Uchwata synodu prowincjonalnego Eowickiego zr. 1556, „Archiwum Komisyi Prawniczej” 1895, t. 1, s. 427439.

32 W. Kriegseisen, op. cit., s. 658-664.

33 Diariusz sejmu walnego warszawskiego z roku 1556/7, wyd. S. B o d n iak, Kórnik 1939, s. 59-62.

34 Zakład Narodowy im. Ossolińskich (Biblioteka Ossolineum), 1045/II, s. 65-68: Reces Sejmu Warszawskiego [1556/7 r.]; J. Szu js ki, Dzieje Polski, t. II: Jagielloni, Lwów 1862, s. 276-277.

35 I. Kaniewska, op. cit., s. 166.

36 Dzienniki sejmów walnych..., s. 148, 152-153. 
nie układały się jednak od początku pomyślnie. Projekt izby poselskiej o rewindykacji królewszczyzn był nie do przyjęcia dla senatu i monarchy. Izba poselska domagała się ponadto wykluczenia z przyszłej elekcji duchownych. Zdaniem Bałakiera „przez pozbawienie biskupów wpływu na elekcję króla, łatwiej byłoby przeprowadzić wybór króla sprzyjającego reformacji" ${ }^{37}$. Niewątpliwie koronowanie protestanta zmieniałoby całkowicie układ sił w sejmie i umożliwiłoby powstanie Kościoła narodowego, co uniemożliwiali katoliccy Jagiellonowie. Postulatu izby poselskiej o wykluczenie duchownych z przyszłej elekcji nie należy jednak identyfikować z koncepcją osadzenia na tronie innowiercy. W toku obrad okazało się bowiem że był to środek nacisku na kler w celu zmuszenia go do ustępstw, a nie stanowcze żądanie. Szlachta za cenę umożliwienia biskupom udziału w elekcji króla domagała się zniesienia jurysdykcji duchownych nie tylko w kwestii herezji, ale również w sprawach o dziesięciny czy w kwestiach małżeńskich ${ }^{38}$. Połączenie problemu jurysdykcji duchownych z egzekucją dóbr uniemożliwiło jednak porozumienie. W wyniku tego kolejny sejm zakończył się brakiem zgody między duchownymi a szlachtą. Część izby poselskiej, obawiając się, że na kolejnym sejmie sytuacja się powtórzy, postulowała na zakończenie zjazdu oddzielenie kwestii wyznaniowych od programu naprawy państwa ${ }^{39}$. Izba poselska zaczęła najwyraźniej uświadamiać sobie, że przyjęcie programu egzekucyjnego od „deski do deski” jest w obecnej sytuacji niemożliwe do zrealizowania i należy w niektórych kwestiach ustąpić lub pójść na kompromis z królem i senatorami, żeby uchwalić w formie konstytucji sejmowych przynajmniej część postulatów ze swojego programu polityczno-gospodarczego. Burzliwy przebieg obrad sejmu spowodował odmienny od założonego dla ruchu egzekucyjnego skutek. Zygmunt August przez następne trzy lata w ogóle nie zwoływał sejmu i przez cały ten okres pozostawał na Litwie ${ }^{40}$.

W tym samym roku do Korony został wysłany nowy nuncjusz Bernardo Bongiovanni, biskup Camerino - dyplomata, zwolennik rozmowy, negocjator ${ }^{41}$. Legata papieskiego czekało wiele trudności i to nie tylko ze strony protestantów, ale również episkopatu polskiego. W 1559 r. zmarł bowiem prymas Mikołaj Dzierzgowski, a jego miejsce zajął biskup chełmski Jan Przerębski, zwolennik reformy Kościoła katolickiego, a nie poczynań kontrreformacyjnych wymierzonych bezpośrednio w protestantów, na które liczył Rzym ${ }^{42}$. Po zakończonym zjeździe członków rady królewskiej w Łomży, w grudniu 1561 r., okazało się

37 E. Bałakier, op. cit., s. 99.

38 Dzienniki sejmów walnych..., s. 154-161, 183-196.

39 Ibidem, s. 282-291.

40 U. Borkowska, Dynastia Jagiellonów w Polsce, Warszawa 2011, s. 73-74; W. Zakrzewski, op. cit., s. 118.

$41 \quad$ P.W. Fabisz, Wiadomość o legatach i nuncjuszach..., s. 135-137.

42 H. Kowalska, Przerębski Jan, [w:] Polski stownik biograficzny, t. 28, Warszawa 1984, s. 748-762; J. Kory tkowski, Arcybiskupi gnieźnieńscy. Prymasowie i metropolici polscy, t. III, Poznań 1889, s. 229271. 
ponadto, że episkopat koronny jest bardzo podzielony. Jakub Uchański, przyszły prymas, postulował utworzenie Kościoła narodowego i porozumienie się z protestantami ${ }^{43}$. Niektórzy domagali się ponadto zniesienia celibatu, jeszcze inni wnosili o udzielanie komunii pod dwiema postaciami i sprawowanie liturgii w języku polskim ${ }^{44}$. Postulaty te pokrywały się z wysłanymi już w 1555 r. przez Zygmunta Augusta propozycjami kompromisu do zatwierdzenia przez papieża Pawła IV. Biskupi przestraszeni szerzącą się reformacją w państwie przy jednoczesnych atakach izby poselskiej i świeckich członków senatu, obawiając się utraty swojej uprzywilejowanej pozycji i beneficjów, z których czerpali ogromne dochody, byli gotowi pójść na ustępstwa i współuczestniczyć w powstaniu Kościoła narodowego.

Nowe możliwości w ustanowieniu tegoż Kościoła w Koronie otwierała wspomniana śmierć prymasa Dzierzgowskiego. Na jego miejsce król wskazał w połowie kwietnia 1562 r. Jakuba Uchańskiego, mimo iż powszechnie znana była jego chęć reformy Kościoła i porozumienia się z protestantami. Uchański nie tylko utrzymywał przyjazne relacje z Andrzejem Fryczem Modrzewskim, ale również popierał w wielu aspektach jego koncepcję Kościoła narodowego. W myśl polskiego reformatora Kościół miał być: powszechny, obejmujący wszystkie wyznania chrześcijańskie, hierarchiczny, a zarazem odwołujący się do norm chrześcijaństwa pierwotnego poprzez zdemokratyzowanie, liturgię w języku polskim, komunię pod dwiema postaciami, zniesienie celibatu duchownych. Najwyższą władzę miał sprawować sobór i zależny od niego papież. W tej ostatniej kwestii Uchański był jednak kurialistą. Awans Uchańskiego może zastanawiać, bo przecież Zygmunt August, mimo lawirowania między katolikami a protestantami, zawsze w ostateczności opowiadał się po stronie Kurii Rzymskiej. Możliwe, że ostatni z Jagiellonów przygotowywał się do powołania Kościoła narodowego przy zachowaniu zwierzchności papieskiej, co pokrywało się z przekonaniami nowego prymasa.

Praktycznie wszyscy badacze podkreślają, że najbardziej dogodne uwarunkowania do wprowadzenia Kościoła narodowego w Koronie nastąpiły w 1552 i 1555 r. Nie należy się z tym wnioskiem jednak zgodzić. Na sejmach w tych latach szlachta co prawda najgłośniej domagała się powołania Kościoła narodowego, jednak duchowni członkowie senatu byli temu przeciwni. Monarcha swoją aprobatę uzależniał od zgody papieża, której jednak nie było. Do ustanowienia Kościoła narodowego skupiającego wszystkich chrześcijan w Polsce, na wzór angielski lub w oparciu o postulaty Uchańskiego, potrzebna była zgoda wszystkich trzech stanów sejmujących. Zgodę izby poselskiej, świeckich i duchowych członków senatu oraz monarchy w tej kwestii można było osiągnąć dopiero od grudnia 1561 r., kiedy to właśnie biskupi i Zygmunt August opowiedzieli się w Łomży za

43 T. Wierzbowski, Jakub Uchański, arcybiskup gnieźnieński. Monografia historyczna, Warszawa 1895, s. 198-199; B. Ku mor, op. cit., s. 146; J. Kor y tkow ski, op. cit., s. 272-418.

44 W. Kriegseis en, op. cit., s. 661-662; J. B u kowski, Dzieje reformacyi w Polsce od wejścia jej do Polski aż do jej upadku, t. II: Polityczny wzrost i wzmaganie się reformacji aż do sejmu w r. 1558/59, Kraków 1883, s. 190-236, 264-267, 425-447; W. Za krzewski, op. cit., s. 113-138. 
kompromisem z protestantami. Dogodne warunki polityczne na ustanowienie Kościoła narodowego trwały jednak krótko. Po śmierci Pawła IV konklawe wybrało na jego następcę Giovanniego Angelo de Medici, który przyjąt imię Piusa IV (6 stycznia 1560 r.). Zaraz po wyborze odciął się od działań swojego poprzednika, zapowiadając reformy w Kościele. Ograniczył działania inkwizycji i doprowadził do wznowienia obrad soboru trydenckiego z dniem 18 stycznia 1562 r. ${ }^{45}$ Już w pierwszych miesiącach obrad uchwalono reformy, które uniemożliwiały Kościołowi katolickiemu w Polsce kompromis z innowiercami. 16 lipca 1562 r. odrzucono postulat udzielania komunii św. pod dwiema postaciami, a we wrześniu było już wiadomo, że celibat nie zostanie zniesiony. $\mathrm{O}$ ile na początku upatrywano w soborze trydenckim instytucji, która przeprowadzi reformę Kościoła i doprowadzi do pojednania katolików z protestantami, o tyle jego ostatnia trzecia faza ostatecznie przekreśliła te nadzieje i przyczyniła się do pogłębienia rozłamu pomiędzy wyznaniami chrześcijańskimi. Uchwały soboru niewątpliwie jednak doprowadziły do reform w Kościele katolickim i zahamowały rozwój wyznań protestanckich.

Zygmunt August nie zdecydował się podnieść na sejmie piotrkowskim 1562/1563 kwestii powołania Kościoła narodowego, postanowił zaczekać na zakończenie obrad soboru ${ }^{46}$. Wprowadzane w Trydencie reformy spowodowały również wycofanie przez biskupów, a nawet i samego Uchańskiego swojego wcześniejszego poparcia dla ustanowienia Kościoła narodowego. Możliwe, że gdyby kolejny sejm odbył się na początku 1562 r., przed podjęciem uchwał soboru, w Koronie zostałby powołany Kościół narodowy, zwłaszcza że Zygmunt August na przełomie 1561 i 1562 r. postanowił przystąpić do obozu egzekucyjnego i wspólnie ze szlachtą przeprowadzić reformy państwowe. Monarcha zaangażowany w konflikt o Inflanty ustąpił izbie poselskiej i za cenę opodatkowania się szlachty w celu sfinansowania działań militarnych wyraził zgodę na rewindykację królewszczyzn i całkowite zniesienie jurysdykcji sądów duchownych nad szlachtą̨ ${ }^{47}$ Należy podkreślić jednak, że ostatni Jagiellon stronił od powołania Kościoła narodowego. Jedynie ze względów politycznych i chęci doprowadzenia do wewnętrznej zgody w kraju zastanawiał się nad taką ewentualnością. Zygmunt August znakomicie orientował się w panującej sytuacji w kraju i zapewne zdawał sobie sprawę, że powołanie Kościoła narodowego nie dawało gwarancji pokoju i pojednania religijnego w Koronie, a nawet wręcz przeciwnie, mogło spowodować powstanie kolejnego wyznania - narodowego. Ruchy protestanckie były ze sobą skłócone i z trudem wypracowywały wspólne stanowisko w kwestii powołania Kościoła narodowego. O rozbiciu wewnętrznym protestantów najlepiej świadczy to, jak wielkie trudności towarzyszyły im w uchwaleniu zgody sandomierskiej w 1570 r. Co równie istotne, katolicy nadal stanowili

45 R. Fischer-Wollpert, op. cit., s. 135-136.

46 E. Godlew ski, Spory szlachty o dziesięciny i jurysdykcje duchownych na sejmach egzekucyjnych 1562-1565, „Białostockie Teki Historyczne” 2013, t. 11, s. 54-63.

47 Diariusz sejmu walnego koronnego piotrkowskiego 1562/3, [w:] Źródtopisma do dziejów Unii Korony Polskiej i Wielkiego Księstwa Litewskiego, wyd. A.T. D zi i ły ńsk i, t. II, cz. 2, Poznań 1856, s. 4-186. 
zdecydowaną większość w kraju, mimo iż nie odzwierciedlała tego struktura reprezentacji sejmowej, co zniechęcało monarchę do forsowania wizji Kościoła narodowego.

W październiku 1563 r. jako legat i nuncjusz apostolski przybył do Korony Giovanni Francesco Commendone. Pod koniec grudnia, po zakończeniu obrad soboru trydenckiego, do kraju wrócił kardynał Stanisław Hozjusz ${ }^{48}$. Obaj duchowni byli przeciwni zawieraniu jakichkolwiek kompromisów z protestantami. Dołożyli ponadto wszelkich starań, aby Zygmunt August zatwierdził postanowienia soboru trydenckiego i nie zgodził się na powołanie Kościoła narodowego. Za przyjęciem reform trydenckich opowiedzieli się również biskupi polscy na czele z prymasem Jakubem Uchańskim. Konsolidacja duchownych w Koronie na skutek uchwał ostatniej fazy soboru trydenckiego spowodowała, że monarcha postanowił odrzucić koncepcję powołania Kościoła narodowego. Na sejmie warszawskim 1563/1564 r. obrady zdominowała kwestia egzekucji dóbr i zawarcia nowej unii z państwem litewskim, tak iż zagadnienie powołania Kościoła narodowego nie było zbyt energicznie przez szlachtę poruszane ${ }^{49}$. Ostatecznie cios marzeniom polskich protestantów o powstaniu Kościoła Polskiego zadał monarcha na sejmie w Parczewie, kiedy 7 sierpnia 1564 r. wspólnie z senatem przyjął księgę ustaw soboru trydenckiego ${ }^{50}$. Uchwały soboru de facto wykluczały możliwość zawarcia kompromisu z innowiercami. Izba poselska ostatnią znaczącą próbę ustanowienia Kościoła narodowego w Koronie podjęła na sejmie piotrkowskim 1565 r. Szlachta postanowiła wykorzystać chęć unieważnienia przez króla jego ślubu z Katarzyną Habsburżanką i postulowała, aby król stanął na czele Kościoła w Polsce i „sam się przypatrzył i dojrzał, kto przy słowie Bożym stoi”. Zygmunt August stanowczo jednak odmówił, tym bardziej że przyjął uchwały soboru trydenckiego ${ }^{51}$. W kwestii unieważnienia ślubu zdał się na papieża. Z powodu podjętych działań i wpływów Habsburgów papież Pius IV nie wyraził zgody na unieważnienie małżeństwa polskiego króla. Mimo to Zygmunt August w kolejnych latach nie przychylił się do postulatu szlachty.

Do powołania Kościoła narodowego w Polsce, jak widzimy, dążyły różne koła i ugrupowania, każde motywowane innymi celami - zarówno o podłożu politycznym, gospodarczym, jak i religijnym. Realizacja celów szlachty zakładała konieczność dokonania gruntownej reformy państwa, w tym całego Kościoła katolickiego w Polsce. Rycerstwo uważało, że sprawą jedności religijnej w kraju winien się zająć polski sobór narodowy z królem na czele,

48 Pamiętniki o dawnej Polsce z czasów Zygmunta Augusta obejmujace listy Jana Franciszka Commendoni do Karola Boromeusza, t. I-II, wyd. M. Malinowski, Wilno 1851, s. 156, 185-186; T. Wierzbowski, op. cit., s. 324-326.

49 Zob. Diariusz sejmu walnego koronnego warszawskiego 1563/4, [w:] Źródtopisma do dziejów Unii..., s. 189419.

50 P. Aleksandrowicz, Przyjęcie przez króla i senat uchwat Soboru Trydenckiego w Parczewie w 1564 r., „Prawo Kanoniczne: kwartalnik prawno-historyczny” 1966, t. 9, nr 3-4, s. 375-379.

51 Dyaryusz Sejmu Piotrkowskiego R. P. 1565 poprzedzony kronika 1559-1562, oprac. W. Ch o m ęt ow ski, wyd. W. Krasiński, Warszawa 1868. 
który to sobór miałby uniezależnić polski Kościół od Rzymu, wprowadzić do liturgii język ojczysty, znieść celibat duchownych, a więc stworzyć w Polsce podstawy Kościoła narodowego. Uprawnienia Kurii Rzymskiej, takie jak: obsadzanie biskupstw, apelacje do Rzymu i opłaty na jego rzecz w postaci annat i świętopietrza, stosowanie prawa kanonicznego, były uważane za ograniczenie pełnej niezależności państwa polskiego. Żądanie to miało tym łatwiejszy posłuch, że wiązało się z nasileniem ruchów reformacyjnych w kraju. Uważano, że przez utworzenie takiego Kościoła wzmocnione zostałyby procesy integracyjne w kraju, ponieważ taki Kościół zjednoczyłby wszystkie wyznania chrześcijańskie, łącznie z prawosławiem. W swoim umiarkowanym skrzydle reformacja miała charakter szlachecki i wyplywała z dążności szlachty do ograniczenia dziesięcin, do odebrania Kościołowi nadmiaru majątków ziemskich i dóbr klasztornych oraz zawężenia zakresu kościelnej jurysdykcji. A zatem istniała bliska więź między reformą religijną a politycznym programem obozu reform. Jednak reforma Kościoła ustąpiła w pierwszej kolejności naprawie finansów państwa, ujednoliceniu krajów koronnych, kwestii unii polsko-litewskiej i konfliktowi o Inflanty. O ile walka o egzekucję praw i dóbr toczyła się praktycznie na wszystkich sejmach koronnych w okresie soboru trydenckiego, o tyle o powstanie Kościoła narodowego zaledwie na dwóch: w 1552 i 1555 r. Na drodze szlachty do realizacji ich programu stanęło duchowieństwo, które z jednej strony broniło swojej uprzywilejowanej pozycji prawnej w państwie, z drugiej strony podejmowało działania torpedujące poddanie Kościoła instytucji państwa. Podziały między wyznaniami protestanckimi i brak stanowczości izby poselskiej w kwestii powołania Kościoła narodowego ułatwiał duchownym członkom senatu walkę ze szlachtą. Izba poselska zdominowana przez protestantów od 1550 r. mogła wywalczyć powstanie takiego Kościoła. Posłowie, kierując się jednak racją stanu, postanowili ustąpić w tej kwestii duchowieństwu, będąc świadomymi, że bez zgody katolików, którzy stanowili większość w państwie, nie mogło być mowy o wspólnym Kościele narodowym. Niechęć do współpracy polskich biskupów z protestantami ewoluowała w kierunku ustępstw i próby pojednania, w celu ustanowienia wspólnego Kościoła o dużej niezależności od Rzymu, jednak nadal pod przewodnictwem papieża. Na skutek podjętych reform w trzeciej fazie soboru trydenckiego (18 stycznia 1562-4 grudnia 1563) polskie duchowieństwo opowiedziało się ostatecznie przeciw powstaniu w Koronie Kościoła narodowego.

Niewątpliwie postawa Zygmunta Augusta była kluczowym czynnikiem, który uniemożliwił powstanie takiego Kościoła. Monarcha, co prawda czasowo, upatrywał w tym możliwość zlikwidowania sporów religijnych, scalenia państwa i unieważnienia swojego trzeciego małżeństwa. Jednak zgodę na powołanie Kościoła narodowego monarcha przez cały okres swojego panowania uzależniał od przychylności instytucji papieskiej, a tej nigdy się nie doczekał. Zygmunt August wychowany w wierze i tradycji katolickiej nie godził się na odrzucenie nauki Kościoła powszechnego. Brak czynnego osobistego zaangażowania ze strony króla w akcję na rzecz większej niezależności Kościoła w Polsce przyczynił się niewątpliwie do upadku myśli o Kościele narodowym. Warto przy tym podkreślić, że król 
usilnie starał się pogodzić oba obozy polityczno-religijne. To dzięki jego wyważonej polityce i balansowaniu między katolikami a protestantami Koronę ominęły wojny religijne, przez które w XVI w. Europa spływała krwią. Mimo iż elity szlacheckie przechodziły na wyznania reformowane, to ludność chłopska stanowiąca większość mieszkańców państwa pozostawała przy wierze swoich przodków i oczekiwała tego samego od swojego króla. Zygmunt August niewątpliwie był pragmatykiem i kierował się racją stanu. Generalizując, powstanie Kościoła narodowego po uwzględnieniu czynników społecznych, religijnych, gospodarczych, politycznych i postawy monarchy było w okresie obrad soboru trydenckiego niemożliwe, zwłaszcza w ostatniej trzeciej fazie tegoż soboru.

\section{Źródła rękopiśmienne:}

\section{BIBLIOGRAFIA}

Archiwum Główne Akt Dawnych, Metryka Koronna: 82, 83, 85.

Biblioteka Kórnicka Polskiej Akademii Nauk (Bibl. Kórnicka), rkps 22885-1.

Zakład Narodowy im. Ossolińskich (Biblioteka Ossolineum), Rękopisy i recesy sejmowe: 1045/II.

\section{Źródła drukowane:}

Diariusz sejmu walnego koronnego piotrkowskiego 1562/3, [w:] Źródtopisma do dziejów Unii Korony Polskiej i Wielkiego Księstwa Litewskiego, wyd. A.T. Działyński, t. II, cz. 2, Poznań 1856, s. 4-186.

Diariusz sejmu walnego koronnego warszawskiego 1563/4, [w:] Źródtopisma do dziejów Unii Korony Polskiej i Wielkiego Księstwa Litewskiego, wyd. A.T. Działyński, t. II, cz. 2, Poznań 1856, s. $189-419$.

Diariusz sejmu walnego warszawskiego z roku 1556/7, wyd. S. Bodniak, Kórnik 1939.

Dyaryusz sejmu piotrkowskiego 1548, [w:] Scriptores Rerum Polonicarum, t. I: Dyaryusze sejmów koronnych 1548, 1553, 1570, wyd. J. Szujski, Kraków 1872.

Dyaryusz Sejmu Piotrkowskiego R. P. 1565 poprzedzony kronika 1559-1562, oprac. W. Chomętowski, wyd. W. Krasiński, Warszawa 1868.

Dzienniki sejmów walnych koronnych za panowania Zygmunta Augusta Króla polskiego i W. X. Litewskiego 1555 i 1558 r. w Piotrkowie ztożonych, wyd. J.T. Lubomirski, Kraków 1869.

Modrzewski A.F., Ad Regem Pontifices, Presbyteros, et Populos Poloniae ac reliquae Sarmatiae, Oratio Andreae Fricii Modrevii de Legatis ad Concilium Christianum mittendis, Kraków 1546.

Pamiętniki o dawnej Polsce z czasów Zygmunta Augusta obejmujące listy Jana Franciszka Commendoni do Karola Boromeusza, t. I-II, wyd. M. Malinowski, Wilno 1851.

Relacye nuncyuszów apostolskich i innych osób o Polsce od roku 1548 do 1690, t. I, wyd. E. Rykaczewski, Poznań 1864.

Uchańsciana, czyli zbiór dokumentów wyjaśniajacych życie i dziatalność Jakóba Uchańskiego, t. IV, Warszawa 1892.

Uchwata synodu prowincjonalnego Eowickiego zr. 1556, „Archiwum Komisyi Prawniczej” 1895, t. 1. Volumina Constitutionum, t. I: 1493-1549, cz. 2, oprac. I. Dwornicka, S. Grodziski, W. Uruszczak, Warszawa 2000.

Wisłocki W., Andrzeja na Więcborku Zebrzydowskiego, biskupa wtoctawskiego i krakowskiego korespondencyja z lat 1546-1553: z przydaniem Synodów z r. 1547 i 1551, jako téż innych dokumentów wspótczesnych, Kraków 1878. 


\section{Opracowania:}

Aleksandrowicz P., Przyjęcie przez króla i senat uchwat Soboru Trydenckiego w Parczewie w 1564 r., „Prawo Kanoniczne: kwartalnik prawno-historyczny” 1966, t. 9, nr 3-4.

Bałakier E., Sprawa Kościota narodowego w Polsce XVI wieku, Warszawa 1962.

Borkowska U., Dynastia Jagiellonów w Polsce, Warszawa 2011.

Bukowski J., Dzieje reformacyi w Polsce od wejścia jej do Polski aż do jej upadku, t. II: Polityczny wzrost i wzmaganie się reformacji aż do sejmu w r. 1558/59, Kraków 1883.

Dembiński B., Kwestia soboru narodowego w Polsce, [w:] Pamiętniki Drugiego Zjazdu Historyków Polskich we Lwowie, t. 1, Lwów 1890.

Fabisz P.W., Wiadomość o legatach i nuncjuszach apostolskich w dawnej Polsce (1075-1863), Ostrów 1864.

Fabisz P.W., Wiadomość o synodach prowincjonalnych i diecezjalnych gnieźnieńskich i o prawach Kościota Polskiego, Kępno 1861.

Fischer-Wollpert R., Leksykon papieży, tłum. B. Białecki, Kraków 1996.

Flaczyński F., Idea Kościota narodowego w Polsce w XVI w., „Ateneum Kapłańskie” 1911, t. 5.

Frankiewicz C., Ze studiów nad soborem narodowym w Polsce, Rzeszów 1914.

Godlewski Ł., Spory szlachty o dziesięciny i jurysdykcję duchownych na sejmach egzekucyjnych 15621565, „Białostockie Teki Historyczne” 2013, t. 11.

Godlewski Ł., Szlachta a duchowieństwo na sejmach w latach czterdziestych i pięćdziesiątych w XVI wieku, „Saeculum Christianum” 2016, t. 23, https://doi.org/10.21697/sc.2016.23.12.

Gołębiowski S., Czasy Zygmunta Augusta, Wilno 1851.

Moraczewski J., Dzieje Rzeczypospolitej Polskiej z pierwszej potowy szesnastego wieku, Poznań 1849.

Kaniewska I., Matopolska reprezentacja sejmowa za czasów Zygmunta Augusta 1548-1572, „Zeszyty Naukowe Uniwersytetu Jagiellońskiego" 1988, z. 48.

Korytkowski J., Arcybiskupi gnieźnieńscy. Prymasowie i metropolici polscy, t. II, Poznań 1888, t. III, Poznań 1889.

Kowalska H., Przerębski Jan 1510-1562, [w:] Polski stownik biograficzny, t. 28, Warszawa 1984.

Kriegseisen W., Stosunki wyznaniowe w relacjach państwo-kościót między reformacją a oświeceniem, Warszawa 2010.

Kumor B., Historia Kościota, t. V: Czasy nowożytne - roztam w chrześcijaństwie zachodnim, Lublin 2002.

Litak S., Kościót w Polsce w okresie reformacji i odnowy potrydenckiej, [w:] Historia Kościota, t. III: 1500-1715, red. L.J. Rogier, R. Aubert, M.D. Knowles, tłum. J. Piesiewicz, Warszawa 1986.

Pawiński A., Jana Ostroroga żywot i pismo O naprawie Rzeczypospolitej, Warszawa 1884.

Pociecha W., Arcybiskup gnieźnieński Mikotaj Dzierzgowski prymas Polski, „Nasza Przeszłość: studia z dziejów Kościoła i kultury katolickiej w Polsce” 1947, t. 2.

Sipayłło M., Leszczyński Rafat ok. 1526-1592, [w:] Polski stownik biograficzny, t. 17, Warszawa 1972.

Sokołowski A., Dzieje Polski ilustrowane, t. III: Epoka Jagiellońska, Warszawa 1900.

Sucheni-Grabowska A., Spory królów ze szlachta w ztotym wieku. Wokót egzekucji praw, Kraków 1988.

Szujski J., Dzieje Polski, t. II: Jagielloni, Lwów 1862.

Wierzbowski T., Jakub Uchański, arcybiskup gnieźnieński. Monografia historyczna, Warszawa 1895.

Wijaczka J., Luteranie w Koronie od 1517 do 1795 r., [w:] Kościoty luterańskie na ziemiach polskich (XVI-XX w.), t. I: W czasach Rzeczpospolitej Obojga Narodów, red. J. Kłaczkow, Torun 2012.

Zakrzewski W., Powstanie i wzrost reformacji w Polsce 1520-1572, Lipsk 1870. 